\title{
Comparison of an Internal Combustion Engine Derating Operated on Producer Gas from Coal and Biomass Gasification
}

\author{
Muhammad Ade Andriansyah Efendi ${ }^{\#}$, N. Nurhadi ${ }^{\#}$ \\ ${ }^{\#}$ R\&D Center for Mineral and Coal Technology (tekMIRA, Ministry of Energy and Mineral Resources, Bandung, 40211, Indonesia \\ E-mail: ade.andriansyah@tekmira.esdm.go.id
}

\begin{abstract}
Producer gas is yield gases from gasification that can be burned, composed by $\mathrm{CO}, \mathrm{H}_{2}$, and $\mathrm{CH}_{4}$, and non-combustible gases like $\mathrm{CO}_{2}$ and $\mathrm{N}_{2}$. Producer gas utilization for internal combustion engine has been studied, not only from biomass gasification but also from coal gasification. This paper compares the research that has done author using coal gasification with other research results using biomass gasification. Coal gasifier performance test conducted with capacity of $20 \mathrm{~kg} / \mathrm{h}$ of coal. The proximate and ultimate analysis of raw coal, ash product and producer gas was conducted and comparised. The result of analysis shows that the efficiency of the coal gasification was $61 \%$ while range of gasifier efficiency for biomass is between $50-80 \%$. Meanwhile, the experimental results on the performance of internal combustion engines using producer gas shows that the derating for power generation using coal producer gas was $46 \%$ and biomass was $20-50 \%$ depend on compression ratio of engine and characteristic of producer gas. Therefore, concluded from the experiment result, producer gas from coal gasification is more promising as fuel for internal combustion engine.
\end{abstract}

Keywords - Coal; Biomass; Gasification; Power Generation; Internal Combustion Engine

\section{INTRODUCTION}

Gasification is a chemical reaction which has a purpose of changing the original solid material into gaseous compounds. By converting solid material into gaseous compounds, the combustion process becomes easier so that the combustion efficiency is increased. The sulphur and nitrogen are also easier separated to obtain cleaner flue gas. Gasification is an effective and clean way to convert coal and biomass into useful fuels and chemical feedstock's [1], [2]. With purification of the fuels produced, they can be directly used in electricity and heat production devices, such as internal combustion engines, or gas turbines [3], [4].

Numerous studies have dealt with gasification of coal or biomass, and its producer gas for power generation. The influence of biomass producer gas fuel properties on spark ignition engines performances was studied [5] in comparison to the natural gas (methane) and digestion biogas. It was shows that to keep $\mathrm{H}_{2}$ molar quota below the detonation value of $64 \%$ for the engines using syngas, characterized by higher hydrogen fraction, the excess air ratio in the combustion process must be increased to 2.2-2.8. As in [6], performance and emissions of a heavy-duty producer gasfuelled engine are analysed and compared to other data found in the literature related to spark ignition engines. The result of this study shows power de-rating during producer gas operation exceeds $50 \%$ because of the significant reduction of the calorific value compared to natural gas operation.

Producer gas utilization for internal combustion engine has been studied, not only from biomass gasification but also coal gasification, however, the derating of the internal combustion engine for each of it has not been compared previously. This paper will discussed the comparison of an internal combustion engine derating when operated on producer gas from coal and biomass gasification.

\section{METHODS}

This paper compares the research that has done by author using coal gasification with other research results using biomass gasification.

\section{A. Coal Gasifier}

Coal gasifier used to generate producer gas (gasification). The gas that coming out from gasifier needs to be further cleaned before it is fed into an internal combustion engine [7]. Producer gas will be passed on purification unit to separate tar and particulate from gas. Also, it will be passed on heat exchangers to reduce the temperature before being inserted into engine. The specification of coal gasifier can be 
seen in Table 1 and the parameter that necessary when producer gas will be used for fuel in internal combustion engines (IC engine) can be seen in Table 2 [8], [9].

TABLE I

THE SPECIFICATION OF COAL GASIFIER

\begin{tabular}{|c|c|c|}
\hline No. & Parameter & Value \\
\hline 1 & $\begin{array}{l}\text { Gasifier } \\
\text { Diameter } \\
\text { Height } \\
\text { Water jacket }\end{array}$ & $\begin{array}{l}30 \mathrm{~cm} \\
120 \mathrm{~cm} \\
10 \mathrm{~cm}\end{array}$ \\
\hline 2 & $\begin{array}{l}\text { Cyclone separator } \\
\text { Diameter }\end{array}$ & 8 in \\
\hline 3 & $\begin{array}{l}\text { Wind cooler } \\
\text { Amount of pipe } \\
\text { Diameter } \\
\text { Length }\end{array}$ & $\begin{array}{l}24 \mathrm{pc} \\
2 \mathrm{in} \\
200 \mathrm{~cm}\end{array}$ \\
\hline 4 & $\begin{array}{l}\text { Heat exchanger } \\
\text { Type } \\
\text { Shell diameter } \\
\text { Tube diameter } \\
\text { Length tube }\end{array}$ & $\begin{array}{l}\text { Shell and tube } \\
8 \text { in } \\
1 \text { in } \\
300 \mathrm{~cm}\end{array}$ \\
\hline 5 & $\begin{array}{l}\text { Scrubber } \\
\text { Diameter } \\
\text { Length }\end{array}$ & $\begin{array}{l}8 \mathrm{in} \\
200 \mathrm{~cm}\end{array}$ \\
\hline 6. & \begin{tabular}{ll}
\multicolumn{3}{l}{ Fog } & drop \\
a. & Type \\
b. & Diameter \\
c. & Length \\
d. & Media
\end{tabular} & $\begin{array}{c}\text { Packed bed } \\
8 \text { in } \\
200 \mathrm{~cm} \\
\text { Ceramic }\end{array}$ \\
\hline 7. & $\begin{array}{l}\text { Gas holder } \\
\text { a. Diameter } \\
\text { b. Length }\end{array}$ & $\begin{array}{l}76 \mathrm{~cm} \\
120 \mathrm{~cm}\end{array}$ \\
\hline 8. & \begin{tabular}{ll}
\multicolumn{2}{c}{ Desulphurizer } \\
a. & Type \\
b. & Media \\
c. Amount \\
d. Diameter \\
e. & Length
\end{tabular} & $\begin{array}{c}\text { Packed bed } \\
\text { Activated carbon } \\
3 \text {, paralelled } \\
8 \mathrm{in} \\
200 \mathrm{~cm}\end{array}$ \\
\hline
\end{tabular}

To fulfil the criteria of the gas that going to enter the motor fuel, gas producer passed into cooling and purification unit which consists of a cyclone separator, air cooler, heat exchangers, fog drop, scrubber and desulphurizer.

TABLE II

PRODUCER GAS PARAMETERS FOR ENGINE USE

\begin{tabular}{|l|l|l|}
\hline \multicolumn{1}{|c|}{ Specification } & Unit & Value \\
\hline Tar content & $\mathrm{mg} / \mathrm{Nm} 3$ & $<100$ \\
\hline Particulate content & $\mathrm{mg} / \mathrm{Nm} 3$ & $<50$ \\
\hline Temperature & ${ }^{\circ} \mathrm{C}$ & $\leq 40$ \\
\hline
\end{tabular}

Design of the gasifier and purification unit can be seen in Fig. 1 and Fig. 2. Cyclone separator was used to separate the particulate that carried in the gas stream. The air cooler and heat exchanger system was used to cool the gas using cooling media (air and water). During this cooling process, condensable components in the gas stream going to condensed, i.e. water, tars and phenols. Condensed component was separated from the gas stream and entered the water seal at the bottom of the air conditioning and water coolers. Scrubber was works to catch the water content, tar and phenols that still carried in the gas stream. The separation of the rest of components was done by contacting the gas and water by spraying it in counter-current mode. Fog drop was functioned to capture residual water content, tars and phenols in the form of small liquid particles (fog) and carried away with the gas flow. Residual water content, tar and phenol, was stick to the surface of the fog drop. Gas holder was used to temporarily store the gas before it passed to the desulphurizer. Desulphurizer was functioned to separate sulphur contained in gas, which consisted of $\mathrm{H}_{2} \mathrm{~S}$, COS and R-S.

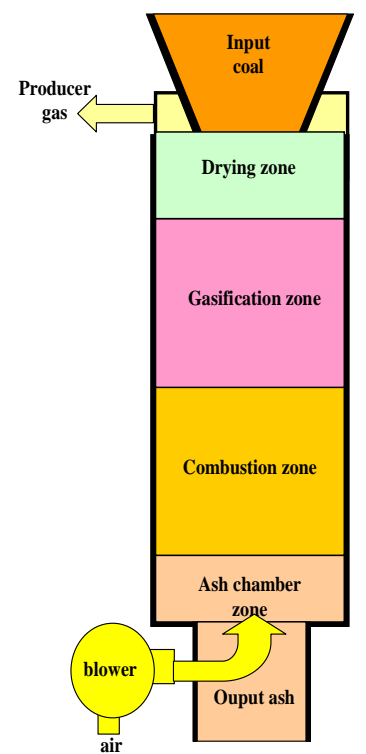

Fig. 1 Schematic diagram of GasMin coal gasification

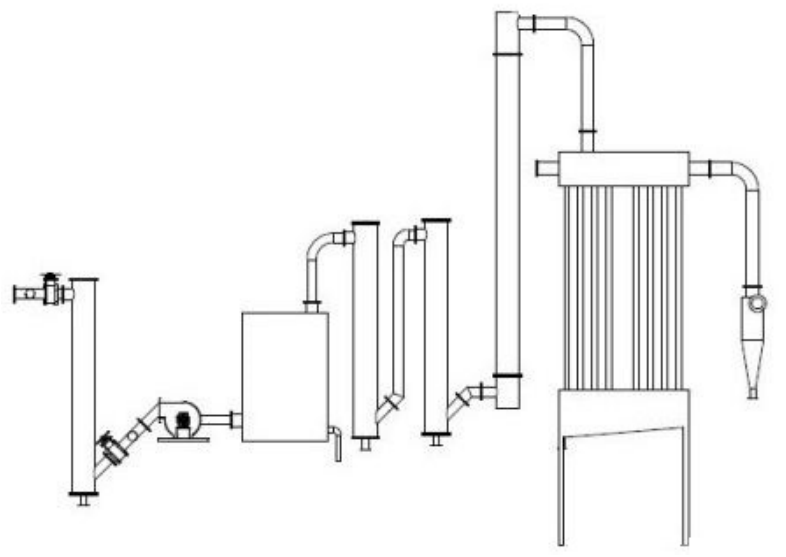

Fig. 2 Gas purification unit

\section{B. Internal Combustion Engine}

This research used $10 \mathrm{~kW}$ genset with type of spark ignition engine. The specification of genset engine can be seen in Table III. 
TABLE III

THE SPECIFICATION OF GENSET ENGINE

\begin{tabular}{|c|c|}
\hline Parameter & Value \\
\hline \multicolumn{2}{|l|}{ Engine } \\
\hline Engine type & $\begin{array}{l}2-\text { cyl, } 4-\text { stroke, forced air } \\
\text { cooling }\end{array}$ \\
\hline Bore $\mathrm{x}$ stroke (mm) & $78 \times 71$ \\
\hline Displacement (mL) & 678 \\
\hline Compressed rate & $8.5: 1$ \\
\hline Rate power kW/(rpm) & $10 \mathrm{~kW} / 3600$ \\
\hline Max. torque N.m/(rpm) & $43.5 /(2500+-200)$ \\
\hline Ignition mode & Thyristor no-contact ignition \\
\hline Lubricant capacity, L & $1.5 \mathrm{~L}$ \\
\hline \multicolumn{2}{|l|}{ Genset } \\
\hline Type & Synchronous generator \\
\hline Volt regulation & Automatic voltage regulation \\
\hline Rated voltage (V) & 380 \\
\hline Phase & 3 phase \\
\hline Rate power (kW) & 9 \\
\hline Max power (kW) & 10 \\
\hline Rate frequency $(\mathrm{Hz})$ & 50 \\
\hline Power factor (cos phi) & 0.8 \\
\hline
\end{tabular}

To utilize producer gas in the genset engine the fuel feed system was modified, the carburettor was replaced with mixing chamber for air and gas producer. Mixing chamber was basically a venturi pipe that connected to the engine intake manifold as can be seen in Fig. 3.

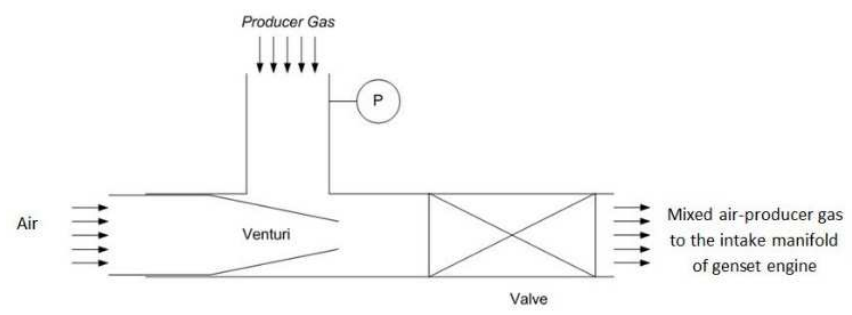

Fig. 3 Mixing chamber for air-producer gas

Low pressure of the air flow in the narrow channel at the venturi will suck up the flow of gas producer and producer gas mixed in the air flow. Comparison of air flow rate and gas producer closely arranged so that the combustion reaction was reached. The result of the calculation of producer gas stoichiometric combustion reaction showed that the mass ratio of air to gas producer was 1.25: 1 or volume ratio was 1: 1 similar as in [10].

At the time of operation, the pressure was kept constant gas producer approached outside air pressure (atmospheric \pm $5 \mathrm{mmH}_{2} \mathrm{O}$ ), with the result that, flow of air and gas producer maintained at a volume ratio of 1: 1 . The experiment started by operating a motor fuel with a no-load power, for 30 minutes. Furthermore, the genset engine loading was done gradually $1 \mathrm{~kW} / \mathrm{h}$. Valve opening level was set manually to maintain the flow rate of mixture air-gas producer in accordance with the needs of the power load of the motor fuel. If the power voltage decreases, the valve arrangement mixture flow rate of air - gas producers will more opened. The addition of power load was stopped when the power supply voltage below the value of $370 \mathrm{~V}$.

\section{Data Analysis}

Coal gasifier performance test conducted with capacity of $20 \mathrm{~kg} / \mathrm{h}$ coal. The proximate and ultimate analysis conducted, with ASTM D3176 and ASTM D7582, on raw coal to know its properties. It's also conducted on the ash as a byproduct of the gasification process. The gasification gas producer will be sampled and inspected for its composition using a gas analyzer. The proximate and ultimate analysis of raw coal that used can be seen at Table IV.

TABLE IIV

THE CHARACTERISTIC OF RAW COAL

\begin{tabular}{|l|l|c|}
\hline Parameter & Unit & Value \\
\hline Proximate & & 11.57 \\
\hline a. Water content & $\begin{array}{l}\%, \text { air dryed basis } \\
\text { (a.d.b.) }\end{array}$ & \\
\hline b. Ash content & $\%$, adb & 1.66 \\
\hline c. Volatile matter & $\%$, adb & 43.42 \\
\hline d. Fixed carbon & $\%$, adb & 43.35 \\
\hline & & \\
\hline Ultimate & & \\
\hline Carbon $(\mathrm{C})$ & $\%, \mathrm{adb}$ & 63.73 \\
\hline Hydrogen $(\mathrm{H})$ & $\%, \mathrm{adb}$ & 6.17 \\
\hline Nitrogen $(\mathrm{N})$ & $\%, \mathrm{adb}$ & 0.96 \\
\hline Sulphur $(\mathrm{S})$ & $\%, \mathrm{adb}$ & 0.16 \\
\hline Oxygen $(\mathrm{O})$ & $\%, \mathrm{adb}$ & 27.32 \\
\hline HHV & $\mathrm{Kcal} / \mathrm{kg}, \mathrm{adb}$ & 5,891 \\
\hline
\end{tabular}

\section{RESULTS AND DISCUSSION}

Producer gas is yield gases from coal gasification that can be burned, composed by $\mathrm{CO}, \mathrm{H}_{2}$, and $\mathrm{CH}_{4}$, and noncombustible gases like $\mathrm{CO}_{2}$ and $\mathrm{N}_{2}$. Besides producer gas, coal gasification also produces ash as a by-product. The results of the analysis (TABLE V) show that the composition of ash has a volatile matter of $7.46 \%$, water content of $4.82 \%$, and fixed carbon of $34.3 \%$. The calculation conducted for ash-removal rate is $5.39 \%$.

TABLE V

THE CHARACTERISTIC OF ASH [11]

\begin{tabular}{|c|l|c|}
\hline Parameter & Unit & Value \\
\hline a. Water content & $\begin{array}{l}\%, \text { air dryed } \\
\text { basis (a.d.b.) }\end{array}$ & 4.82 \\
\hline b. Ash content & $\%$, adb & 53.42 \\
\hline c. Volatile matter & $\%, \mathrm{adb}$ & 7.46 \\
\hline d. Fixed carbon & $\%, \mathrm{adb}$ & 34.3 \\
\hline HHV & $\mathrm{Kcal} / \mathrm{kg}, \mathrm{adb}$ & 3,011 \\
\hline
\end{tabular}

From Table VI, it may be noted that the combustible components of the producer gas constitutes $0.04 \%$ of $\mathrm{H}_{2}$, $34.74 \%$ of $\mathrm{CO}$ and $0.24 \%$ of $\mathrm{CH}_{4}$. The non-combustible components of the producer gas constitute $5.09 \%$ of $\mathrm{CO}_{2}$ and $58.67 \%$ of $\mathrm{N}_{2}$. Among the combustible gases of the producer 
gas, $\mathrm{CH}_{4}$ has a higher calorific value, but its presence is very little in percentage.

TABLE VI

THE SPECIFICATION OF COAL PRODUCER GAS [11]

\begin{tabular}{|l|l|l|}
\hline Parameter & Unit & Value \\
\hline $\mathrm{N}_{2}$ & $\%$ mol & 58.67 \\
\hline $\mathrm{CO}_{2}$ & $\%$ mol & 5.09 \\
\hline $\mathrm{CO}$ & $\%$ mol & 34.74 \\
\hline $\mathrm{O}_{2}$ & $\%$ mol & 1.21 \\
\hline $\mathrm{H}_{2}$ & $\%$ mol & 0.04 \\
\hline $\mathrm{CH}_{4}$ & $\% \mathrm{~mol}$ & 0.24 \\
\hline $\mathrm{HHV}$ & $\mathrm{Kcal} / \mathrm{Nm}^{3}$ & 1,013 \\
\hline Tar content & $\mathrm{Mg} / \mathrm{Nm}^{3}$ & 4.04 \\
\hline Particulate content & $\mathrm{Mg} / \mathrm{Nm}^{3}$ & 11.17 \\
\hline Temperature & ${ }^{\circ} \mathrm{C}$ & 36 \\
\hline
\end{tabular}

The results of calculation of mass and energy balance of the gasification process can be seen in Fig. 4. These results show that the efficiency of the coal gasification was $61 \%$ Range of gasifier efficiency is between $50-80 \%$ that is for coal and biomass gasification. A comparison of the performance results of the gasifier systems are presented in Table VII.

TABLE VII

A COMPARISON OF THE PERFORMANCE RESULTS OF THE GASIFIER SYSTEMS

\begin{tabular}{|c|c|c|c|c|c|c|}
\hline No & $\begin{array}{c}\text { Design } \\
\text { parameters }\end{array}$ & Unit & $\begin{array}{l}\text { Nurhadi } \\
\text { et al [11] }\end{array}$ & $\begin{array}{c}\text { Salam et } \\
\text { al [12] }\end{array}$ & $\begin{array}{c}\text { Plis et al. } \\
{[13]}\end{array}$ & $\begin{array}{l}\text { Martinez } \\
\text { et al. }[14]\end{array}$ \\
\hline 1 & $\begin{array}{l}\text { Equivalence } \\
\text { ratio }\end{array}$ & $\begin{array}{l}\% \text { Mass } \\
\text { fraction }\end{array}$ & 36 & 25 & 29 & 29 \\
\hline 2 & $\begin{array}{l}\text { Calorific value } \\
\text { of the gas }\end{array}$ & $\mathrm{Kcal} / \mathrm{Nm}^{3}$ & 1,013 & 931.50 & $1,313.65$ & 1,242 \\
\hline 3 & $\begin{array}{l}\text { Ash charcoal } \\
\text { removal rate }\end{array}$ & $\begin{array}{l}\% \text { Mass } \\
\text { fraction }\end{array}$ & 5.39 & 21 & $\begin{array}{c}\text { not } \\
\text { available }\end{array}$ & $\begin{array}{c}\text { not } \\
\text { available }\end{array}$ \\
\hline 4 & $\begin{array}{l}\text { Cold gas } \\
\text { efficiency }\end{array}$ & $\begin{array}{l}\% \text { Energy } \\
\text { fraction }\end{array}$ & 61 & 49 & 57.9 & 76.7 \\
\hline
\end{tabular}

\begin{tabular}{|c|c|c|c|c|}
\hline \multirow[b]{2}{*}{ coal feed } & \multicolumn{2}{|l|}{ Coal } & \multicolumn{2}{|c|}{ Producer Gas } \\
\hline & $20 \mathrm{~kg} / \mathrm{hr}$ & $\vee$ & & \\
\hline \multicolumn{2}{|c|}{ Proximate, $\%-w$} & \multirow{5}{*}{ COALGASIFIER } & \multicolumn{2}{|c|}{ Properties, \%-v } \\
\hline $\mathrm{TM}$, ar & $11,57 \%$ & & $\mathrm{H} 2$ & $0,04 \%$ \\
\hline $\mathrm{IM}, \mathrm{adb}$ & $4,53 \%$ & & $\mathrm{CO}$ & $37,68 \%$ \\
\hline \multirow[t]{2}{*}{$a s h, a d b$} & $1,66 \%$ & & $\mathrm{CO} 2$ & $5,09 \%$ \\
\hline & $0,31 \mathrm{~kg} / \mathrm{hr}$ & & $\mathrm{CH} 4$ & $0,24 \%$ \\
\hline Ultimate & & & $\mathrm{CnHm}$ & $0 \%$ \\
\hline C, adb & $63,73 \%$ & $\uparrow$ & 02 & $1,21 \%$ \\
\hline $\mathrm{H}, \mathrm{adb}$ & $6,17 \%$ & & N2 & $\begin{array}{c}55,74 \% \\
100\end{array}$ \\
\hline \multirow[t]{2}{*}{$\mathrm{HHV}, \mathrm{adb}$} & $5.891 \mathrm{kcal} / \mathrm{kg}$ & & $\mathrm{HHV}$ & $1.013 \mathrm{kcal} / \mathrm{Nm} 3$ \\
\hline & & & $\begin{array}{l}\text { Ash } \\
\text { \%ash }\end{array}$ & $\begin{array}{l}0,58 \mathrm{~kg} / \mathrm{hr} \\
53,42 \%\end{array}$ \\
\hline \multirow[t]{6}{*}{ air flow } & 27,292 SCFM & & \multicolumn{2}{|c|}{ Ultimate, \%-w } \\
\hline & $46,37 \mathrm{Nm} 3 / \mathrm{hr}$ & & C, $a d b$ & $38,63 \%$ \\
\hline & & & $\mathrm{H}, \mathrm{adb}$ & $1,33 \%$ \\
\hline & & & HHV & $3.011 \mathrm{kcal} / \mathrm{kg}$ \\
\hline & & Efficiency (CGE) & \multicolumn{2}{|c|}{ ash+charcoal removal rate } \\
\hline & & $61,0 \%$ & 5,3 & \\
\hline
\end{tabular}

Fig. 4 Mass and energy balance calculation of the coal gasification process.

Internal combustion engine performance test conducted using original fuel with octane number 92 as a comparison fuel for genset engine. It was done for performance comparison of producer gas as a fuel for genset engine with the original fuel. The results can be seen in Figure 4.
Fig. 5 shows performance of the genset engine using ron 92 and producer gas as a fuel. The results accordance with the specifications, the engine generates power of $9 \mathrm{~kW}$. While experiment using coal gasifier producer gas, it can generate power of $4.8 \mathrm{~kW}$ and there is a derating of the power generates by $46 \%$. The resulting power loss is attributed to the lower calorific value of producer gas. From Table VI, it may be noted that, only $35 \%$ coal producer gas comprises of combustible gases and $65 \%$ as noncombustible components. Meanwhile, in gaseous-fueled engines or dual-fuel engines running with biomass producer gas, the derating of power output is approximately $20-30 \%$ [15]. Reference [16] shows report an engine operating with biomass producer gas the derating from the designed power rating was in the ranges of $40-50 \%$ when the compression ratio (CR) was 7:1 and $20 \%$ when was $11: 1$. It also similar with another literature where de-rating of the genset engine using biomass producer gas was ranges from 40-50\% [16], [17], [18].

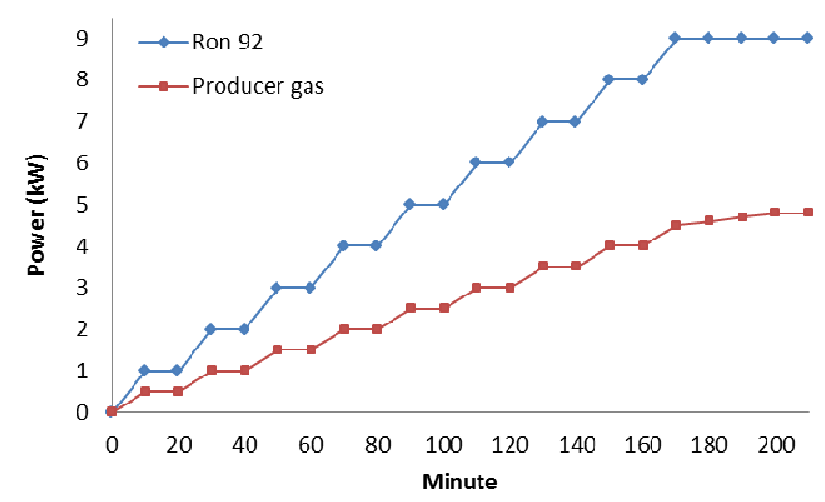

Fig. 5 The result analysis of ron 92 and producer gas as a fuel for genset [11].

The differences between the values reported are caused by the characteristics of the producer gas and the engines used. Producer gas is known as lean gas or low calorific value gas. Since, major portion of producer gas is non-combustible; the producer gas engines are operating at a de-rated design capacity. The non-combustible gas present in producer gas affects the engine's efficiency in two ways. When using the producer gas for operating engines, most of the heat generated during combustion phase is absorbed by the noncombustible components of the producer gas itself. These non-combustible components lower the energy density of producer gas and reduce the adiabatic flame temperature.

In Refs. [19],[20] the used engines diesel and gas respectively, adapted to run with biomass producer gas, and a high CR 17: 1. In Ref [10] that use coal producer gas in spark ignition engine, the CR lower 7:1 this represents a loss of more power in engines when compared with diesel cycle adapted to work with producer gas.

\section{CONCLUSIONS}

The efficiency of the coal gasification was $61 \%$ and range of gasifier efficiency is between 50-80\%. Derating for power generation using coal producer gas was $46 \%$. Meanwhile, in gaseous-fueled engines or dual-fuel engines running with biomass producer gas, the derating of power output is 
approximately 20-30\% for engine with CR 11:1 and 40-50\% for engine with CR 7:1. The differences between the values reported are caused by the characteristics of the producer gas and the engines used. Therefore, producer gas from coal gasification is more promising as fuel for internal combustion engine

\section{ACKNOWLEDGMENT}

The author would like to thank the $R \& D$ Center for Mineral and Coal Technology (tekMIRA), Ministry of Energy and Mineral Resources, who has funded this research.

\section{REFERENCES}

[1] P.N. Sheth, B.V. Babu, "Experimental studies on producer gas generation for wood waste in a downdraft biomass gasifier," Bioresource. Technology, 100, pp. 3127-3133, 2009.

[2] P. Basu, Biomass Gasification and Pyrolysis-Practical Design and Theory, Elsevier. 2010.

[3] S. Murgia, M. Vascellari, G. Cau, "Comprehensive CFD model of an air-blown coal-fired updraft gasifier," Fuel, 101, pp. 129-138, 2012.

[4] S. Kaewluan, S. Pipatmanomai, "Gasification of high moisture rubber woodchip with rubber waste in a bubbling fluidized bed," Fuel Processing Technology, 92, p. 671-677, 2011.

[5] C. Marculescu, F. Alexe, V. Cenus, "Analysis of biomass and waste gasification lean syngases combustion for power generation using spark ignition engines," Waste Management, 47, p.133-140. 2016.

[6] P. Gobbato, M. Masi, M. Benetti, 'Performance analysis of a producer gas-fuelled heavy-duty SI engine at full-load operation," Energy Procedia, 82, p.149-155, 2015.

[7] P. Raman, N. K. Ram, R. Gupta,"A dual fired downdraft gasifier system to produce cleaner gas for power generation: design, development, and performance analysis," Energy, 54, p. 302-314, 2013.

[8] M. Affendi, S. Sugiyatno, I. Djunaedi, H. Wahyu, "Uji Variasi Beban Listrik dan Rasio Gas Hasil Gasifikasi Sekam Padi Pada Mesin Diesel Dual Fuel," Seminar Rekayasa Kimia Dan Proses Jurusan Teknik Kimia Fakultas Teknik Universitas Diponegoro Semarang, 2010, p. D01-1 - D01-6.
[9] P. Hasler and T. Nussbaumer, "Sampling and analysis of particles and tars from biomass gasifier," Biomass and Bioenergy, 18, p. 61 $66,2000$.

[10] R. Reddy, P. Reddy,"Analysis of producer gas carburetor for different air-fuel ratios using CFD." International Journal of Research in Engineering and Technology, Volume: 03, p. 470-474, May 2014.

[11] N. Nurhadi, M. A. A. Efendi, "Utilization of coal gasification producer gas for power generation using 10kw spark ignition engine", Indonesian Mining Journal, 19 (1), p.16-26, 2016.

[12] P.A. Salam, S. C. Bhattacharya, "A comparative study of charcoal gasification in two types of spouted bed reactors," Energy, 31, p.228-243, 2006.

[13] P. Plis, R.K. Wilk, "Theoretical and experimental investigation of biomass gasification process in a fixed bed gasifier." Energy, 36, p.3838-45, 2011.

[14] J.D. Martínez, K. Mahkamov, R.V. Andrade, E. S. Lora, "Syngas production in downdraft biomass gasifiers and its application using internal combustion engines," Renewable Energy, 38(1), p.1-9, 2012.

[15] N.R. Banapurmath, P.G. Tewari, Comparative performance studies of a 4-stroke CI engine operated on dual fuel mode with producer gas and Honge oil and its methyl ester (HOME) with and without carburetor, Reneweable Energy, 34 (4), p. 1009-1015, 2009.

[16] G. Sridhar, R. B. Yarasu, "Facts about producer gas engine, Paths to sustainable energy," Dr Artie Ng (Ed.), ISBN: 978-953-307-401-6, InTech, 2010, Available from: http://www.intechopen.com/books/ pathsto-sustainable-energy/facts-about-producer-gas-engine.

[17] S. Tsiakmakis, D. Mertzis, A, Dimaratos, Z. Toumasatos, Z. Samaras, "Experimental study of combustion in a spark ignition engine operating with producer gas from various biomass feedstocks." Fuel, 122, p 126-139, 2014.

[18] P. Raman, N.K. Ram, "Performance analysis of an internal combustion engine operated on producer gas, in comparison with the performance of the natural gas and diesel engines," Energy, 63, p. 317-333, 2013.

[19] L. Shuying, W. Guocai, P. De Laquil, Biomass gasification for combined heat and power in Jilin province, People's Republic of China, Energy Sustain. Development, 5 (1), p 47-53, 2001.

[20] D. Prando, F. Patuzzi, G. Pernigotto, A. Gasparella, M. Baratieri, Biomass gasification systems for residential application: an integrated simulation approach, Applied Thermal Engineering, 71 (1), p 152-160, 2014. 